\section{Goran Milovanović ${ }^{1}$}

University of Niš, Faculty of Economics

Slavoljub Milovanović ${ }^{2}$

University of Niš, Faculty of Economics

Tanja Spasić ${ }^{3}$

Higher Business School of Applied Studies, Leskovac
SCIENTIFIC REVIEW ARTICLE doi:10.5937/ekonomika1601043M

Received: December 7, 2015

Accepted: February 11, 2016

\title{
THE ROLE OF CONTEMPORARY WEB TECHNOLOGIES IN SUPPLY CHAIN MANAGEMENT
}

\begin{abstract}
Ever changing market circumstances and globalization have caused electronic business (e-business) and supply chain management to integrate and virtual supply chains to emerge. E-business comprises all forms of business transactions and information sharing which is performed using information and communication technologies between companies, companies and their consumers, or companies and public administration. Supply chain is thus considered a unique and continuous business process, supported with goods and information flows throughout the entire distribution channel, where each company is part of the chain and boundaries between companies are non-existent. In times of economic uncertainty, cost reduction through rationalization and automatization of business processes, and improvement of productivity and quality of goods and services, become necessary for company's survival. In this context, the role of information and communication technologies in supply chain management is discussed, with particular attention to the contemporary web technologies such as extranet and Web 2.0.
\end{abstract}

Key words: Supply chain management, virtual supply chain, e-business, extranet, Web 2.0

JEL classification: L86

\section{УЛОГА САВРЕМЕНИХ ШЕВ ТЕХНОЛОГИЈА У УПРАВЉАЊУ ЛАНЦИМА СНАБДЕВАЊА}

\begin{abstract}
Апстракт
Променљиве тржишне околности и глобализащија утицали су на интегрисање електронског пословања (е-пословање) и управљања ланцима снабдевања као и на настанак виртуелних ланаца снабдевања. Е-пословање обухвата све облике пословних трансакција или размене информација које се изводе коришћењем информационих и комуникаџионих технологија
\end{abstract}

\footnotetext{
${ }^{1}$ goran.milovanovic@eknfak.ni.ac.rs

${ }^{2}$ smilovan@eknfak.ni.ac.rs

${ }^{3}$ tanja-spasic@hotmail.com
} 
између предузећа, предузећа и његових купаца или између предузећа и јавне администрачије. Ланаи снабдевања се ставља у контекст јединственог пословног прочеса, робног и информационог тока који га прати дуж ияелог канала дистрибуције, а свака појединачна компанија је само једна карика у ланиу снабдевањ у у коме више не постоје границе између компанија. Увремену економских изазова, смањење трошкова кроз рачионализачију пословања и аутоматизацију процеса, повећање продуктивности и квалитета производа и услуга, услови су опстанка компанија на тржишту. У том контексту се разматра улога информащионих и комуникационих технологија, а пре свега савремених веб технологија, као што су екстранет и Wеб 2.0, у управљању ланцима снабдевања.

Кључне речи: Управљање ланием снабдевања, виртуелни ланаи снабдевања, е-пословање, екстранеt, Web 2.0

\section{Introduction}

The supply chain consists of a series of processes and activities that allow for, direct or indirect, satisfaction of customer needs. All flows of information, products, or cash generate costs in the supply chain while its only source of income is the customer. Due to the increased market transparency and accessibility of information, physical borders of cooperation are wider and more open. In such conditions, the concept of global business networking is becoming increasingly accepted.

The development of information technology has contributed to, among other things, the emergence of virtual businesses. Virtual company is characterized by a virtual organizational structure. Its members take advantage of the joint expertise and market performance. Furthermore, they enjoy the benefits in terms of sharing costs and risks. The virtual supply chain is based on the information technology and electronic communication among all of its participants.

E-commerce and e-procurement significantly transform supply chains. Although these forms of e-business applications have been the subject of a number of studies in previous years, the possibility of e-collaboration can be far more important for the transformation of modern supply chains.

Effective supply chain management is essential for a successful company. It needs to go beyond the boundaries of a single company, in order to effectively exchange information between it and all other participants in the supply chain. In this regard, the Internet, electronic data interchange, and extranet technology can play an important role.

Corporate portals offer a single point of access to critical business information within the organization, via Internet browsers. In addition, Web 2.0 should be adopted throughout the supply chain. Companies that were among the first to adopt this network technology achieved significant competitive advantage. Such technology redirects users from passive reading information on the Internet to active network participation and the creation of different information content. 


\section{Supply chains as business networks}

The supply chain is more than a mere sum of connections that are manifested in the process starting from the extraction of raw materials to the use of finished products by end users (Mentzer, DeWitt, Keebler, Min, Nix, Smith, Zacharia, 2001, pp. 1-25). Highly integrated supply chains connect resources of several organizations in order to meet customer requirements in a timely and efficient manner.

Supply chain managers should find opportunities to use technology that will, at an acceptable cost level, create value for end users. They should also enable the efficient flow of information, cash, services, materials, and finished goods from the supplier's supplier to the customer's customer. The extent to which these objectives can be realized directly points to the success of supply chain management.

The concept of supply chain management has a relatively short history. It was defined at the beginning of the $21^{\text {st }}$ century, but is based on concepts that are decades old (Brian, Joe Clifford, Haozhe, 2013).

This concept appeared in literature in early 1980s. It was first discussed by Keith Oliver and Michael Webber - Booz Allen \& Hamilton company consultants. In 1982, their views were first published in German in the magazine "Wirtschaftswoche", and then in English, in the journal "Outlook", published by the company Booz Allen \& Hamilton (Franklin, Meissner, 2014, p. 11). At that time, the concept of supply chain management was associated with collaborative specialization and reduction of inventory within and outside the company. Company activities, such as procurement, inventory management, warehousing, order processing, and transport, were executed independently. Each activity had its own budget, priorities, processes, and key performance indicators. Such defragmentation led to sub-optimum and prevented companies to operate at the lowest total cost (Frankel, Keller, Keller, Gibson, Hanna, Defee, Chen, Tate, Sanders, Goldsby, Iyengar, Rao, Fawcett, Fawcett, Moon, 2014).

Figure 1: From functional silos to supply chain management

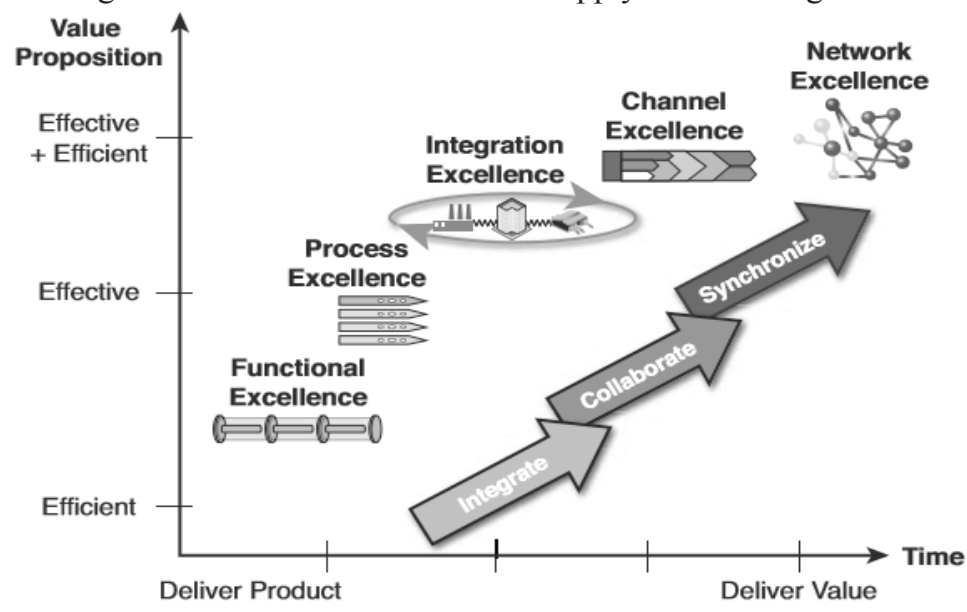

Source: Brian, Joe, Clifford, \& Haozhe (2014). The Definitive Guide to Integrated Supply Chain Management, New Jersey: Pearson Education, p. 16. 
After identifying the problem of defragmentation, company managers integrate related activities, such as inbound transportation, procurement, and production, to support production. Furthermore, inventory management, order processing, outbound transportation, and related activities become an integral part of the function of physical distribution. These two areas (inbound and outbound flows in the company) were later integrated in the logistics function.

The real supply chain occurs when companies synchronize their related processes and adopt a holistic philosophy of managing its interdependent strategic areas, such as finance, marketing, planning, and technology.

Although the concept of supply chain management has evolved rapidly in the last three decades, many companies are just beginning to implement it. In contrast, in many companies, the implementation of this concept is in the maturity stage (See Figure 1). Companies that adopt the concept of supply chain management later must replace the management of their independent functions (functional silos) with the management of integrated internal business processes, as well as adopt a single target performance of costs and services. This is often the most challenging step the companies must take from the management of functions to supply chain management. This is followed by the establishment of external relations and implementation of the concept of the enlarged company. Cooperation with key suppliers and customers, as well as application of modern technology, allow companies to combine different channels in order to create value. The final step in the evolution of the concept of supply chain management is the development of complex, dynamic, resilient, and organizationally responsive network (business related participants) for the flow of raw materials, materials, information, finished goods, and cash. Modern supply chains are based on networking partners. Traditional ways of collaboration among companies in the supply chain are no longer sustainable. The concept of global business networking allows business networks to take a dominant market role from individual companies. In relation to individual companies, business networks can quickly respond to unpredictable demand for products or services whose life expectancy is constantly shortened.

Today, supply chain management involves the management of continuous processes that create added value, starting from the procurement of materials, services, and information to the delivery of finished products to the end users, to meet their real needs. The functioning of the modern supply chains is nearly impossible without the use of modern technology. Of special importance is the application of various forms of electronic business and electronic interchange of data on demand, inventory, and/or production among supply chain members. The aim of its application is not to eliminate participants in the supply chain, or disintermediation (Janssen \& Sol, 2000, pp. 407-417), but improving efficiency and/or effectiveness of its processes, activities, and flows. What is more, modern technology generates new structures in the supply chain and enables companies to electronically choose their business partners on the global market.

The implementation of different programs for inventory management can improve collaboration of members in the supply chain. One such program is Vendor Managed Inventory (VMI), implemented by companies in other fields of business.

By implementing VMI program, Walmart, for example, successfully transfers responsibility for product inventory management in their retail outlets to manufacturers or dealers from which it procures the product (Yuliang, Yan, Martin, 2012, pp. 979- 
1001). In addition to increasing access to the real demand of customers and inventory levels, VMI program allows manufacturers and dealers to adequately distribute goods to individual customers, to increase the level of service to customers, and reduce costs of transportation, inventory, and sales. Furthermore, by relying on VMI program, manufacturer and dealer are able to fully support the objectives of other members in the supply chain. Due to the implementation of VMI, suppliers can: develop better decision support systems, achieve a higher level of automation and control of logistics processes, shorten the lead-time, and reduce total costs. Besides Walmart, VMI program is successfully implemented in the following companies: GlaxoSmithKline, Electrolux Italia, Nestle, Tesco, Boeing, and Alcoa (Tarikere \& Stephan, 2012, p. 940).

\section{Virtual supply chains}

Unlike conventional logistics systems, virtual supply chain is based more on sharing information than on identifying the optimal amount of inventory and its location. It allows for the flexible (Christiaanse \& Kumar, 2000, pp. 268-285) choice of partners in production and distribution.

Virtual companies reduce the need for physical resources to the necessary minimum, thus significantly reducing the costs of its outputs. Virtual company is a sort of an open-type company. It is not just one company but a whole range of networked companies that together form a virtual supply chain.

The main reasons for the formation of virtual supply chains are economic interests of each member in the supply chain, i.e. their desire to be better prepared, in relation to the competitors, to face the growing business risk and uncertainty and achieve significant savings in transaction costs. Companies in the virtual supply chain need to opt for those business activities that they can perform better than their competitors. Key benefits of virtual supply chains are: flexibility, reduced paper documents, decentralization, faster access to selected markets, high adaptability to customer requirements, development of partnerships and alliances, increased competitiveness. To increase competitiveness on the virtual market, companies must procure goods or services from other members on the virtual market that offer these products at lower cost and higher quality.

Virtual supply chains have certain disadvantages as well. Some of the most significant are: loss of knowledge due to the exchange of experience and knowledge among chain members may in the future create new competitors, reduction in profits due to the use of external sources, lack of control over a part of the business, lack of reliability of the Internet, and others.

Unlike virtual organizations, virtual supply chains are production and distribution systems using a physical network structure. They hire production and distribution specialists, members of different supply chains. They are oriented to specific tasks and rapid response. They have no permanent members, but include new for the purposes of specific projects. New members do not need to be known to other members in the virtual chain. 


\section{E-business and supply chain management}

The rapid growth of e-business creates huge challenges in supply chain management in the public and private sectors. This issue is a constant subject of interest of executives and directors, as companies strive to "keep up" with rapid changes and improve logistics processes, to ensure permanent, first-class product delivery to customers. The integration of many elements of the supply chain is the biggest business challenge for many companies, because it implies transforming their fragmented business processes into electronically controlled and integrated processes (Croom, 2001).

Supply chains are complex economic systems, which extend from raw materials to consumption of final goods and services. There is also the growing competition among supply chains themselves, and then among individual organizations.

Experience of organizations in the implementation of e-business shows how much they are dependent on their suppliers and distribution channels. The ability of the organization to successfully manage its supply chain is a key strategic challenge. At the core of supply chain management is the recognition that the organization is able to utilize the skills, capacities, and resources of its suppliers and distributors, as well as its own resources, in order to achieve success on the selected markets.

Electronic business transforms supply chains. A special role in this process belongs to the following forms of e-business application: e-commerce, e-procurement, and e-collaboration (Johnson \& Whang, 2002, pp. 413-423).

E-commerce helps network partners within the supply chain to identify and give a rapid response to changing customer requirements, researched on the Internet. The basic idea of e-commerce is that information exchange interconnects customers and dealers, without any physical contact with the product. E-commerce has had a significant impact on the supply chains of many products. Of course, information supply chain has undergone major changes. Manufacturers of physical products have also turned to the Internet, as a direct distribution channel. Direct channel includes a different set of decisions and challenges than those in the existing physical retail distribution channels. These two types of channels differ in the types of customers, operations related to the execution of orders, cost structure, realized profits, logistics requirements, the expected quality of the services provided, the level of market sharing, access to information, and return of goods. For example, by using differentiated prices, e-dealer can motivate clients to wait with their order, and in this way gain significant information in relation to market demands.

The advantages of e-commerce in relation to traditional sales channels are reflected in the flexibility of delivery time or the configuration of logistics. In creating a distribution system in e-commerce, the flow of materials and information can be separated, and the delivery process can have a different way from the order flow. For example, someone can order the book from the website amazon.com, but the actual delivery can be made from the warehouse of this website's distributor - Ingram Books. In this way, the online company may, in addition to its own, construct the virtual logistics network, consisting of logistic assets of its suppliers and dealers.

E-procurement allows companies to use the Internet in order to procure direct or indirect material, as well as to manage the services that generate additional costs, such as transportation, storage, customs services, payment, and quality assurance. 
Due to fierce competition, changable customer requirements, shortened product lifecycle, and expanded variety of products, modern production requires flexibility. In addition to the dynamic capacity distribution, efficient procurement of materials is the basis of flexible production. Internet is a "natural" platform for realizing effective procurement, as many customers and dealers find each other easily and work together in harmony on the basis of pre-defined protocols.

While e-procurement is a "mirror" of e-commerce, they differ significantly. While, for example, e-commerce mainly involves a large number of individual customers, e-procurement mainly cooperates only with other companies.

There are three different procurement strategies for manufacturers. The first strategy is known as a strategic partnership, and focuses on developing and maintaining long-term supply relationship with a certain supplier. The second strategy is the purchase over the Internet at a lower price. The third strategy combines the previous two and is implemented by signing long-term sales and purchase agreement with the supplier, but to a certain level and if necessary, additional quantities can be purchased over the Internet from other suppliers.

E-procurement raises the possibility of a combined strategy and creates optimal solutions in it. Lower costs of searching for suppliers, materials, prices, etc. significantly affect the procurement strategy.

Some software solutions take real-time data (inventory level, data on sales and market prices on the electronic stock exchange) and provide a good insight into the operational status and the possibility to optimize operations.

E-collaboration includes coordination of various decisions and activities in addition to transactions among partners in the supply chain, including suppliers and customers, carried out via the Internet. For example, this includes coordination of changes in the specification of materials, made by engineers, in conjunction with the product manufactured by an external partner.

E-collaboration is an interaction between two or more companies via the Internet. Interaction goes beyond simple sales and purchase transactions and may be better described with the word "connectedness". This includes activities such as exchange of information and integration, exchange and coordination related to some decisions, as well as exchange of processes and resources. The execution of these activities carries with it a number of dilemmas and issues that supply chain and logistics managers may face: Where to place the goods? Where to open facilities (production, warehouse, retail)? Which facility capacity to plan? How many products to manufacture, store, place, and from which facilities?

\section{The role of the Internet, electronic data interchange and extranet technology in supply chain management}

Supply chain management requires the use of, above all, a system for the exchange of information among its members. In addition to the application of internal IT systems, such as enterprise resource planning, the use of identification technology should also be considered, such as RFID and other wireless technology. In addition, supply chain 
management would not be possible if its participants did not have access to a wide range of external technology services.

Nothing so deeply transforms the process of supply chain management as the Internet. It has a big influence on how companies communicate with each other and with their customers. Former factors limiting the integration of the supply chain, such as high transaction costs between partners, poor access to information, and difficult management of complex interfaces among companies, simply disappear on the Internet (Christopher, 2005 , p. 5).

Information flow management has always been critical for supply chain management. In the era of the Internet, because of the rapid flow of information based on computer networks, information management gets a primary role in creating successful supply chain.

The Internet is the most cost-efficient means for the integration of the supply chain. It transforms many processes within the supply chain, from raw material procurement through product design to customer management. It also provides an opportunity to all suppliers in the supply chain to coordinate data transfer.

Supply chain management systems are essential for the successful operation of many companies. They rely on various forms of information technology, the most important being: electronic data interchange and extranet.

The technology of electronic data interchange (EDI) enables business partners to electronically routinely share documents in accordance with pre-agreed standards. This technology offers numerous advantages compared to manual document delivery. First of all, it minimizes data entry errors, because each entry is checked by the computer. The length of messages can be shorter and the messages are safer. It also shortens the product delivery time and the execution of other activities in the logistics process, increases productivity, and improves customer service levels. Finally, it reduces the costs of storage and use of paper documents.

The technology of electronic data interchange also manifests certain disadvantages that need to be considered before its implementation. It is sometimes necessary to restructure business processes to fit the requirements of this technology. What is more, there are numerous standards of electronic data interchange in use today. Therefore, an enterprise must use several standards to be able to communicate with multiple business partners. The possibility of the company's quick access to the Internet is also important, and that the files on the product design, product photos, and catalogs are routinely sent by electronic mail. Therefore, the value of the shortened and structured e-commerce message, from several thousand XML bytes to a few hundred EDI bytes, is negligible. Due to the higher Internet speed, EDI technology is increasingly replaced by XML network services.

Extranet technology. The influence of the Internet on the process of supply chain management has been studied, among others, by Walters and Reinbird (Walters \& Rainbird, 2007, p. 601). They have come to realize that only by integrating information management strategy and supply chain management can companies successfully compete on the global market.

Graham and Hardaker have proven that, through the use of extranet, companies can target new markets, by offering low initial costs and greater flexibility (Graham \& Hardaker, 2000, p. 290). By outsourcing and the formation of strategic alliances, 
companies encourage sharing of business information among suppliers and customers, which was once the property of the competitors and participants from other industries. Graham and Hardaker also argue that business is conducted in an environment where sharing information among all the participants in the supply chain leads to fundamental changes in their interaction, but also in the entire business practice. For example, the three largest car manufacturers in the United States have launched an exchange of information in the car industry in order to maximize the use of the effects of computer networks and electronic business communities. The results were lower costs in the entire automotive industry. At the same time, these benefits have significantly altered the competitive strategy and interaction among all participants in this industry.

Research of supply chains and value chains has shown that, by implementing extranet, companies manage to significantly reduce operating costs and increase profits (Cohen \& Roussel, 2005, p. 124; Steinfield, Markus \& Wigand, 2011, pp. 75-108). It also suggests that companies should review the entire supply chain and identify areas in which they can carry out revolutionary or evolutionary change by using the Internet technology.

The company can use the Internet networking standards and web technology to create private (internal) network, called the intranet. To develop a web-based supply chain management system, companies must link different business partners' intranets, in order to create extranet. Extranet connects business partners via the Internet, giving them access to certain areas of their own intranet. The main objective of extranet is to encourage collaboration among business partners in the supply chain (Guah \& Currie, 2006, p. 45).

The company can provide extranet access to certain suppliers, customers, and other partners. Extranet allows people outside the company to cooperate and communicate across the network with its staff. It also allows external business partners to access the corporate intranet via the Internet, not only to track the status of their orders and inventory levels but also to intensify collaboration.

The main advantages of extranet include: faster information and process flows, more efficient ordering and customer support, lower costs (communication costs, travel costs, and unnecessary administration), and more profitable business. The company chooses the type of extranet depending on the business partner and the purpose of the supply chain. Extranet uses the virtual private network technology (VPN) to make the communication via the Internet safer (Figure 2).

Figure 2: Information flows in extranet through secure virtual private connections

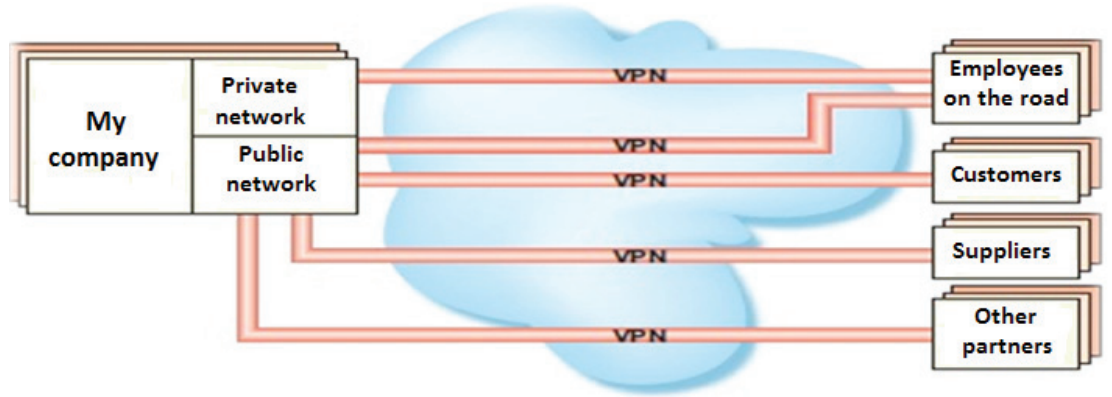


Extranet can be classified according to various criteria. From the viewpoint of the participants in the extranet development and its main users, there are industrial extranet and extranet for the support to joint ventures and other business partnerships.

Industrial extranet. Just like one company can develop extranet, several large companies in one industry may join to create extranet, thus bringing benefit to all. Such a network can allow companies to cooperate successfully and is safe global medium for B2B information exchange. In addition, it can be used for business transactions essential for a particular job among the leading companies in the aviation, automotive, chemical, and electronic industries, as well as financial and health institutions, logistics, manufacturing, transportation, and related industries. Industrial extranet provides customers with reliable extranet connections, as well as services in the field of virtual private connections.

Extranet can be used in many different ways in the supply chain management. Table 1 provides a brief overview of extranet possibilities in this field of management.

\section{Table 1: Possibilities of using extranet in supply chain management}

\begin{tabular}{|c|c|}
\hline Number & Usability \\
\hline 1. & $\begin{array}{l}\text { - For finding, selecting, and ordering items by customers via online distributors' catalog and } \\
\text { directly from the supplier, without any human contact }\end{array}$ \\
\hline 2. & - For tracking shipments and equipment using road, rail, and air traffic \\
\hline 3. & $\begin{array}{l}\text { - For contacting suppliers or customers in relation to delayed deliveries, no product in stock, } \\
\text { and changing the agreed delivery date }\end{array}$ \\
\hline 4. & $\begin{array}{l}\text { - For reserving space in public warehouses for the expected delivery in certain locations and } \\
\text { markets }\end{array}$ \\
\hline 5. & - For scheduling outgoing delivery from private and public distribution centers, 24 hours a day \\
\hline 6. & - For receiving orders from international customers \\
\hline 7. & - For checking the status of orders with suppliers \\
\hline 8. & - For notifying suppliers on modifications to the product configuration \\
\hline 9. & - For electronic payment of invoices and financial balance checks \\
\hline 10. & $\begin{array}{l}\text { - For direct communication via electronic mail with suppliers, customers, etc. about potential } \\
\text { problems in supply, } 24 \text { hours a day }\end{array}$ \\
\hline 11. & - For a faster response to customer complaints \\
\hline 12. & - For arranging shipments and delivery \\
\hline 13. & - For reducing costs and response time \\
\hline
\end{tabular}

As regards extranet for the support to joint ventures and other business partnerships, partners in the joint venture use its possibilities and tools for communication and 
collaboration. For example, a company that provides insight into the mortgage quotas for owners of real estate and which sells mortgages via the Internet can use the extranet to connect its business partners.

\section{The use of portals and Web 2.0 technology in supply chain management}

Information technology has been applied in supply chain management for more than three decades. However, its implementation is still associated with high costs and uneven level of acceptance by different members of the same supply chain. The intensive development of web technology has increased the possibilities for the application of Web 2.0 in the supply chain management (Keng, Alain, Boon, 2011, pp. 394-399).

Corporate portals allow companies and their suppliers to work closely together. There are two basic types of corporate portals: procurement portals (for the company's suppliers - "upstream" segment of the supply chain) and distribution portals (for customers - "downstream" segment of the supply chain). Procurement portals automate business processes related to the purchase and supply of products between one customer and several suppliers. Distribution portals automate business processes in connection with the sale or distribution of products between one supplier and multiple customers (Yoo, Choudhary \& Tridas, pp. 145-170).

In order to find a competitive advantage, companies must look at the value chains of suppliers, distributors, and customers. Using extranet and web portals, the company sends the order when inventory falls below a specified level. In the system of quick response, like this, the products are pulled through the channel by demand ("pull" model), instead of being "pushed" through the channel from inventory ("push" model). In this way, the need for inventory is reduced.

In terms of the number of processes, activities, and participants, as well as the nature of the relationships among the participants, supply chains significantly differ from each other. It is very tempting to copy the success of other companies in the supply chain management. However, this can often be a mistake, because the circumstances are not the same in all supply chains. Therefore, there is no universal way of managing supply chains. Companies, especially those operating in traditional sectors of the economy, generally do not want to change their logistics activities into primarily electronic formats. Such changes require large and very expensive procedures, even if they can lead to long-term profit and savings. Supply chain management should change the culture, not only at the level of the company and its national supply chain, but also at the level of international supply chains.

Web 2.0 (also known as "social networks", "social revolution", or "user-generated content") has been developed in the last ten years, to cover the rapid development of the Internet and its related technology and applications. Web 2.0 has been inspired by business revolution in the computer industry, caused by increased "relocation" of business to the Internet platform, but also by trying to understand the rules of success on that new platform (Barlow, 2011, p. 466).

The essence of Web 2.0 lies in the sharing of information through the interconnectedness of people. It is focused on openness and relationship-building. 
The driving force of Web 2.0 lies in the creation of applications and services within the unique Internet environment, which can be used for creating and sharing information among the users. A large number of services, technology, and applications that connect to Web 2.0 are blogs, Internet encyclopedias (the so-called "Wikis"), social networks, forums, services for sharing multimedia content (for example, YouTube), text and multimedia messaging (SMS and MMS), and instant messaging (MSN, Skype, WhatsApp, Viber, and other applications).

\section{Table 2: Examples of use of modern web applications in the supply chain}

\begin{tabular}{|c|c|}
\hline Web 2.0 tool & Examples of applications in the supply chain \\
\hline Blog & $\begin{array}{l}\text { Blogs can be used for internal and external communication. For example, they can be } \\
\text { used for publishing the news about business development. What is more, blogs are a } \\
\text { good place for presenting products and services, sharing experts' advice, opinions, and } \\
\text { frequently asked questions. Finally, blogs can be used to create a database of loyal } \\
\text { customers. }\end{array}$ \\
\hline $\begin{array}{l}\text { Internet } \\
\text { encyclopedias } \\
\text { (Wikis) }\end{array}$ & $\begin{array}{l}\text { Internet encyclopedias allow companies to exchange documents and intensify mutual } \\
\text { cooperation. They can also encourage communication and transfer of knowledge } \\
\text { between people involved in the supply chain. }\end{array}$ \\
\hline Forums & $\begin{array}{l}\text { Forums may serve the company to build business connections, exchange information } \\
\text { and opinions. The company can also use forums to seek advice on issues related to } \\
\text { business, and thus improve its expertise. }\end{array}$ \\
\hline $\begin{array}{l}\text { RSS (Really Simple } \\
\text { Syndication) } \\
\text { "feeds" }\end{array}$ & $\begin{array}{l}\text { RSS allows companies/individuals to check for new content on the Internet. When } \\
\text { new content appears on the relevant external website, the user gets notified and the } \\
\text { information is delivered. This can be useful for market research and for the transfer of } \\
\text { information, i.e. knowledge. }\end{array}$ \\
\hline Social networks & $\begin{array}{l}\text { Social networks are especially useful to companies when they advertise products and } \\
\text { collect feedback from customers about the advertised products in order to create a base } \\
\text { of loyal customers. }\end{array}$ \\
\hline $\begin{array}{l}\text { Sharing multimedia } \\
\text { content }\end{array}$ & $\begin{array}{l}\text { Companies can use tools and technology for sharing multimedia content, both to } \\
\text { present their products and services and to display photos and videos of best practices } \\
\text { within the supply chain. }\end{array}$ \\
\hline Tagging & $\begin{array}{l}\text { "Tagging" on social networks can serve companies as a means of categorization, } \\
\text { classification, and labeling of content and valuable information on the Internet. It could } \\
\text { eventually contribute to the collection of business data and market research. }\end{array}$ \\
\hline
\end{tabular}

Source: Barlow 2011, p. 467.

Numerous fields and network tools can be used for improving communication in the supply chain. Web 2.0 activities that can be particularly helpful include: marketing and advertising, cooperation and strengthening ties with customers and suppliers, transfer of information and knowledge, creating added value as regards products and services, research and development. Examples of specific Web 2.0 applications and tools in supply chains are given in Table 2.

Only a few studies focus on the application of Web 2.0 in supply chain management. For example, Goh, Lee, and He and Tan analyzed the impact of this technology on the 
creation of potential benefits through dynamic B2B integration, but did not show in detail how this technology can support the overall practice of supply chain management (Goh, Lee, He \& Tan, 2007). Furthermore, Ooi, Alain and Tan proved that this technology can be applied in the process of supply chain management, but did not provide explanation of how it can support this entire process (Ooi, Alain \& Tan, 2011, pp. 394-399). Limited results of these and numerous other studies point to the fact that, regardless of the expansion of the implementation of Web 2.0, it is still not entirely clear how it can be used to support the operation of supply chains. These restrictions will be a serious challenge for researchers and managers in the future.

\section{Conclusion}

Competition among companies is increasingly replaced by competition among supply chains. Due to global development and application of information technology, supply chains become increasingly complex business networks with a virtual organizational structure. Unlike others, companies that belong to business networks are more flexible and more successful in coordinating business transactions with other members of these networks.

E-business and supply chain management are in modern companies increasingly integrated into a single system that is based on the latest web technology. The structure of supply chains is constantly changing. Their increased effectiveness and efficiency depends not only on technological innovation but also on information and communication technology that supports electronic business. Today's successful supply chain management systems, which rely on modern web technology, allow manufacturers, their suppliers, and customers to achieve a competitive advantage on the market. Companies that adopt this technology on time will have a dynamic and sophisticated supply chain, in line with their electronic business strategies.

The creation of a specific supply chain is influenced by numerous factors. For that reason, nowadays, there are no two identical supply chains.

The introduction of modern web technology greatly reduces the resources required to track the flow of materials and products in the supply chain. This creates conditions for the improvement of their reagibility, competitiveness, and profitability.

Using information and communication technology is considered to be a prerequisite of effective control of complex supply chains. Therefore, the availability of different, adaptable, and price-competitive services with the use of modern technology becomes the foundation of modern supply chain management.

\section{References}

Barlow, A. (2011). Web Technologies and Supply Chains. Glasgow: Caledonian University.

Brian, J.G., Joe, B.H., C. Clifford D., \& Haozhe, C. (2014). Definitive Guide to Integrated Supply Chain Management: Optimize the Interaction between Supply Chain Processes, Tools, and Technologies, New Jersey: Pearson Education. 
Christiaanse, E., \& Kumar, K. (2000). ICT-enabled coordination of dynamic supply webs, International Journal of Physical Distribution and Logistics Management, Vol. 30, No. 4, 268-285.

Christopher, M. (2005). Logistics and Supply Chain Management. Edinburgh: Pearson Education Limited.

Cohen, S., \& Roussel, J. (2005). Strategic Supply Chain Management: The Five Disciplines for Top Performance. New York: McGraw-Hill Companies, Inc.

Croom, S. (2001). Supply Chain Management in the E-Business Era. Coventry: Warwick Business School, SC Associates

Frankel, R., Keller, B.S., Keller, C.B., Gibson, J.B., Hanna, B.J., Defee, C.C., Chen, H., Tate, W., Sanders, R.N., Goldsby, J.T., Iyengar, D., Rao, S., Fawcett, E.S., Fawcett, M.A., Moon, A.M. (2014). Definitive Guides for Supply Chain Management Professionals, Pearson Education.

Franklin, J.R., \& Meissner, J. (2014). Network Orchestration: A modern response to international supply chain complexity, BVL International: The Global Supply Chain Network, Issue 2.

Goh, C.M., Lee, S.P., He, W. \& TAN, P.S. (2007) Web 2.0 Concepts and Technologies for Dynamic B2B Integration. Singapore: Singapore Insitute of Manufacturing Technology.

Graham, G., \& Hardaker, G. (2000). Supply $\square$ chain management across the Internet. International Journal of Physical Distribution \& Logistics Management, Vol. 30 Issue 3-4, 286-295.

Guah, M.W., \& Currie, W.L. (2006). Internet Strategy: The Road to Web Services Solutions. Hershey: Idea Group Inc.

Janssen, M., \& Sol, H.G. (2000). Evaluating the role of intermediaries in the electronic value chain. Internet Research: Electronic Networking Applications and Policy, 10/5, 407-417.

Johnson, M.E., \& Whang, S. (2002). e-Business and Supply Chain Management: An Overview and Framework. Production and Operations Management, Volume 11, Issue 4, 413-423.

Keng, B.O., Alain, Y.L.C., \& Boon, I.T, (2011). Application of Web 2.0 in Supply Chain Management: A Brief Overview, Trends in Applied Sciences Research, 6, 394-399.

Mentzer, T.J., DeWitt, W., Keebler, S.J., Min, S., Nix, W.N., Smith, D.C., Zacharia, G.Z. (2001). Defining Supply Chain Management, Journal of Business Logistics, Vol. 22, No. 2, 1-25.

Ooi, K. B., Alain, Y.L. \& Tan, B.I. (2011). Application of Web 2.0 in Supply Chain Management: A Brief Overview. Trends in Applied Sciences Research, 6, 394399.

Steinfield, C.W., Markus, M.L., \& Wigand, R.T. (2011). Through a glass clearly: standards, architecture, and process transparency in global supply chains. Journal of Management Information Systems, Vol. 28, No. 2, 75-108. 
Tarikere, T.N., \& Stephan M.W. (2012). Prerequisites to vendor-managed inventory. International Journal of Production Research, Vol. 50, No. 4, 939-951.

Walters, D., \& Rainbird, M. (2007). Cooperative innovation: a value chain approach. Journal of Enterprise Information Management, Vol. 20, Issue 5, 595-607.

Yoo, B., Choudhary, V., \& Tridas, M. (2011). A study of sourcing channels for electronic business transactions. Journal of Management Information Systems, Vol. 28, No. 2, 145-170.

Yuliang, Y., Yan, D., \& Martin, D. (2012). Supply Chain Learning and Spillovers in Vendor Managed Inventory, Decision Sciences, Vol. 43, Issue 6, 979-1001. 